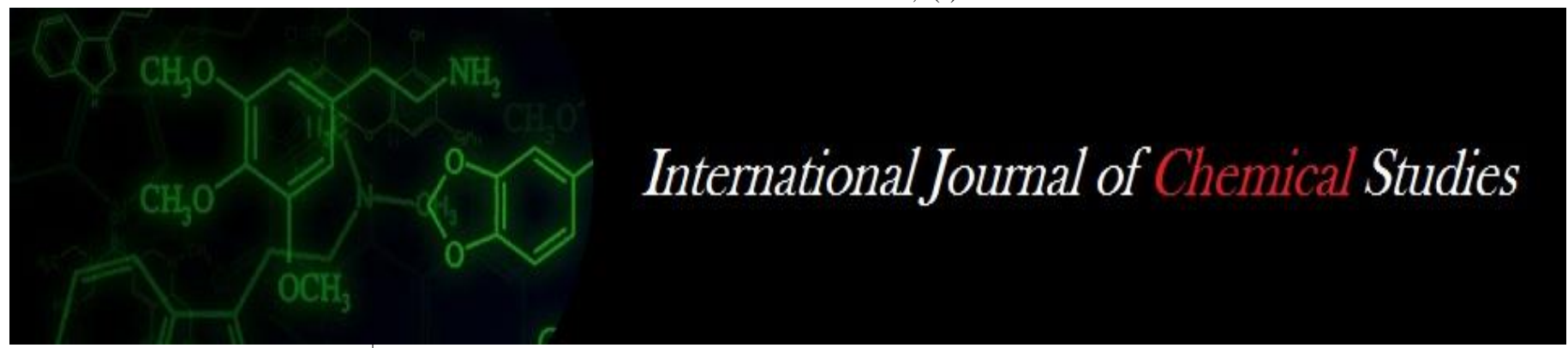

P-ISSN: 2349-8528

E-ISSN: 2321-4902

www.chemijournal.com

IJCS 2020; 8(4): 3344-3348

(C) 2020 IJCS

Received: 10-05-2020

Accepted: 12-06-2020

Muddana Sri Sai Charan Satya School of Natural Resource

Management, College of Post Graduate Studies in Agricultural Sciences, Central Agricultural University, Umiam (Barapani), Meghalaya, India

Sanjay-Swami

School of Natural Resource Management, College of Post Graduate Studies in Agricultural Sciences, Central Agricultural University, Umiam (Barapani), Meghalaya, India
Corresponding Author: Muddana Sri Sai Charan Satya School of Natural Resource Management, College of Post Graduate Studies in Agricultural Sciences, Central Agricultural University, Umiam (Barapani), Meghalaya, India

\section{Response of black gram (Vigna mungo L. Hepper) to phosphorus and boron fertilization in acidic soil of Meghalaya}

\author{
Muddana Sri Sai Charan Satya and Sanjay-Swami
}

DOI: $\underline{\text { https://doi.org/10.22271/chemi.2020.v8.i4ap.10168 }}$

\begin{abstract}
A field experiment was conducted to understand the response of black gram (Vigna mungo L. Hepper) to phosphorus and boron fertilization in acidic soil of Meghalaya. For this, four levels of phosphorus (0, 25, $\left.50,75 \mathrm{~kg} \mathrm{P}_{2} \mathrm{O}_{5} \mathrm{ha}^{-1}\right)$ and four levels of boron $\left(0,0.5,1.0,1.5 \mathrm{~kg} \mathrm{~B} \mathrm{ha}^{-1}\right)$ were tested in field with sixteen treatment combinations and replicated thrice in split plot design. The native soil had pH 4.99, E.C. 0.42 $\mathrm{dS} \mathrm{m}{ }^{-1}$, organic carbon 1.32 percent, available nitrogen $251.35 \mathrm{~kg} \mathrm{ha}^{-1}$, available phosphorus $13.68 \mathrm{~kg} \mathrm{ha}$ ${ }^{1}$, available potassium $233.24 \mathrm{~kg} \mathrm{ha}^{-1}$ and hot water soluble boron $0.054 \mathrm{ppm}$. The results revealed that application of phosphorus and boron had synergistic effect on growth and yield of black gram. The plant height of black gram increased with crop development stages i.e. 30 DAS, 60 DAS and at maturity. Increasing phosphorus and boron doses also increased plant height over control at all crop development stages i.e. 30 DAS, 60 DAS and at maturity. The highest plant height at maturity stage under different phosphorus doses was recorded at $75 \mathrm{~kg} \mathrm{P}_{2} \mathrm{O}_{5} \mathrm{ha}^{-1}$ as $43.43 \mathrm{~cm}$. However, the significant increase in plant height was observed up to $50 \mathrm{~kg} \mathrm{P}_{2} \mathrm{O}_{5} \mathrm{ha}^{-1}$ with $42.89 \mathrm{~cm}$. Similarly, under different boron doses, the highest plant height $(42.60 \mathrm{~cm})$ was observed at $1.5 \mathrm{~kg} \mathrm{~B} \mathrm{ha}^{-1}$ whereas, the lowest plant height was recorded in control plots of $\mathrm{P}$ and $\mathrm{B}$ as 36.58 and $38.17 \mathrm{~cm}$, respectively at maturity. The seed yield of black gram increased with increasing phosphorus and boron doses. The highest seed yield $\left(10.12 \mathrm{q} \mathrm{ha}^{-1}\right)$ among different phosphorus doses was observed at $75 \mathrm{~kg} \mathrm{P}_{2} \mathrm{O}_{5} \mathrm{ha}^{-1}$. However significant increase in seed yield was recorded up to $50 \mathrm{~kg} \mathrm{P}_{2} \mathrm{O}_{5} \mathrm{ha}^{-1}$ with $9.52 \mathrm{q} \mathrm{ha}^{-1}$. Similarly, in case of boron, the significant increased seed yield was observed up to $1.0 \mathrm{~kg} \mathrm{~B} \mathrm{ha}^{-1}\left(9.13 \mathrm{q} \mathrm{ha}^{-1}\right)$ yet the highest seed yield was recorded as $9.43 \mathrm{q} \mathrm{ha}^{-1}$ with $1.5 \mathrm{~kg} \mathrm{~B} \mathrm{ha}^{-1}$. The interaction effect of phosphorus and boron on seed yield was also found significant. The lowest seed yield was observed in control at $\mathrm{P}_{0} \mathrm{~B}_{0}\left(5.56 \mathrm{q} \mathrm{ha}^{-1}\right)$ and significantly high seed yield was observed at $\mathrm{P}_{50} \mathrm{~B}_{1.5}\left(10.35 \mathrm{q} \mathrm{ha}^{-1}\right)$ at phosphorus within boron, and in boron within phosphorus, it was recorded $11.03 \mathrm{q} \mathrm{ha}^{-1}$ at $\mathrm{P}_{75} \mathrm{~B}_{1}$.
\end{abstract}

Keywords: Phosphorus, boron, acidic soil, black gram, growth and yield

\section{Introduction}

Phosphorus $(\mathrm{P})$ is the second essential macronutrient necessary for the normal growth and development of plants (Brady and Weil, 2008; Sanjay-Swami and Singh, 2020) [1, 2]. P fertilization is the major determinant of the mineral nutrient yield in legume crops. Applied phosphorus greatly affects the yield efficiency of pulse crops (Nasreen et al., 2006; Sailo and Sanjay-Swami, 2019) ${ }^{[3,4]}$. It is a key component of nucleic acids, phospholipids and ATPs and plays a role in a number of plant cellular processes such as cell division, energy storage and transition, respiration, photosynthesis and enzymatic activity. It involves the development of seedling, growth of early roots, early heading formation and accelerates crop maturity (Alinajoati and Mirshekari, 2011) ${ }^{[5]}$. Plants also require phosphorus for growth, sugar and starch utilization, photosynthesis, nucleus formation, and cell division (Atif et al., 2014) ${ }^{[6]}$.

Boron is also an important micronutrient that plays a crucial role in multiple physiological and biochemical processes in plant bodies such as cell division and enlargement, cell wall formation, sugar translocation, metabolism of carbohydrates, metabolism of nitrogen and water relations (Oyinlola, 2007; Marschner, 2012) ${ }^{[7,8]}$. At plant level, the key role of B includes the development of floral organs, flower male fertility and pollen tube growth (Gupta and Solanki, 2013) [9]. According to Rio Tinto (2012) ${ }^{[10]}$ boron is one of the crucial micronutrients for plants because it plays a role in the metabolism of carbohydrates, in the production of grain, strengthens the cell wall structure and stimulates specific metabolic 
pathways, increases carbohydrate transport and increases enzyme activity. The role of boron (B) within the plant includes cell wall synthesis, sugar transportation, cell division, differentiation, membrane functioning, root elongation, plant hormone regulation, and plant generative growth (Marschner 1995) ${ }^{[11]}$. Boron is also essential in cell elongation, cell division (Camacho-Cristobal et al., 2015) ${ }^{[12]}$; it boosts plant growth and ultimately increases plant height. It is essential for the translocation of sugars, starches, phosphorus, etc., and helps in nitrogen absorption and nodular formation (Singh et al. 2006) ${ }^{[13]}$.

The response to a particular nutrient not only depends on its own level but also on the levels of other nutrients present in soil. Interaction occur when the level of one production factor influence the response to other factor. These interactions may be synergetic (positive) leading to the increased availability of other plant nutrient or antagonistic (negative) in which availability of other plant nutrient adversely affected. Phosphorus deficiency may prevent the efficient use of boron (Nelyubova and Sychev, 1969) ${ }^{[14]}$. Decreased concentration of DNA and RNA in phosphorus deficiency became more pronounced as both boron and phosphorus were deficient together. This may be due to the fact that phosphorus is an integral part of nucleotides (Bould 1983; Hundt et al., 1970) $[15,16]$ which form nucleic acids and boron, since it is necessary for the synthesis of certain nucleic acid components and its deficiency is involved in nucleic acid degradation (Kevresan et al., 1977; Dugger, 1983) ${ }^{[17,18]}$. The increased decline in nucleic acids in combined boron and phosphorus deficiency likely causes a chain reaction. Depression in RNA can cause protein depression resulting in impaired growth and dry weight depression. The increase in acid phosphatase activity could be due to the effect of either boron or phosphorus deficiency in the accumulation of inorganic phosphate (Hewitt and Tatham 1960) ${ }^{[19]}$. More pronounced increase in the activity of polyphenol oxidase and peroxidase in the combined deficiency of boron and phosphorus may be due to the potential accumulation of o-diphenol like substances in deficiency of B (Hewitt 1983) ${ }^{[20]}$.

Black gram (Vigna mungo L. Hepper) is one of the most important pulse crops grown in Meghalaya. It contains about $25-26 \%$ protein, $60 \%$ carbohydrates, $1.3 \%$ fat, and is the richest in phosphoric acid among the all pulses (Tamang and
Sanjay-Swami, 2017) [21]. Responses of black gram to nutrients such as nitrogen, phosphorus, sulphur and boron have been found to vary with different soil, crop and climatic conditions (Tamang and Sanjay-Swami, 2019) ${ }^{[22]}$. Meghalaya soils are highly acidic, and phosphorus and boron are poor in supply. Inadequate use of $\mathrm{P}$ and $\mathrm{B}$ are among the major factors responsible for low yields. A search of literature revealed that no systematic study has been conducted so far to investigate the combined effect of phosphorus and boron on black gram in this region. Therefore, the present study was undertaken to investigate the response of black gram to phosphorus and boron fertilization in acidic soil of Meghalaya.

\section{Materials and Methods}

A field experiment was conducted at School of Natural Resource Management, College of Post Graduate Studies in Agricultural Sciences, Central Agricultural University, Umiam during kharif 2019 with four levels of phosphorus i.e. 0, 25, 50 and $75 \mathrm{~kg} \mathrm{P}_{2} \mathrm{O}_{5} \mathrm{ha}^{-1}$ applied though Single Super Phosphate (SSP) and four levels of boron $0,0.5,1.0,1.5 \mathrm{~kg} \mathrm{~B}$ $\mathrm{ha}^{-1}$ applied through borax in sixteen treatment combinations. The experiment was laid out in Split Plot Design and replicated three times. Black gram (var. PU-31) was raised as test crop following standard package of practices and harvested at maturity. Before initiating the trial, a surface soil sample $(0-15 \mathrm{~cm}$ depth) from the experimental farm was collected, processed and analysed for various physiochemical characteristics which are presented in Table 1.

Table 1: Initial physico-chemical properties of the experimental soil

\begin{tabular}{|c|c|}
\hline Parameters & Value \\
\hline Soil texture & Sandy clay loam \\
\hline $\mathrm{pH}(1: 2.5)$ & 4.99 \\
\hline $\mathrm{EC}\left(1: 2.5 \mathrm{dSm}^{-1}\right)$ & 0.42 \\
\hline Organic carbon $(\%)$ & 1.32 \\
\hline Available $\mathrm{N}\left(\mathrm{kg} \mathrm{ha}^{-1}\right)$ & 251.35 \\
\hline Available $\mathrm{P}\left(\mathrm{kg} \mathrm{ha}^{-1}\right)$ & 13.68 \\
\hline Available K $\left(\mathrm{kg} \mathrm{ha}^{-1}\right)$ & 233.24 \\
\hline Available B $(\mathrm{ppm})$ & 0.054 \\
\hline
\end{tabular}

The recorded week-wise standard meteorological parameters during crop period are depicted in Fig. 1.

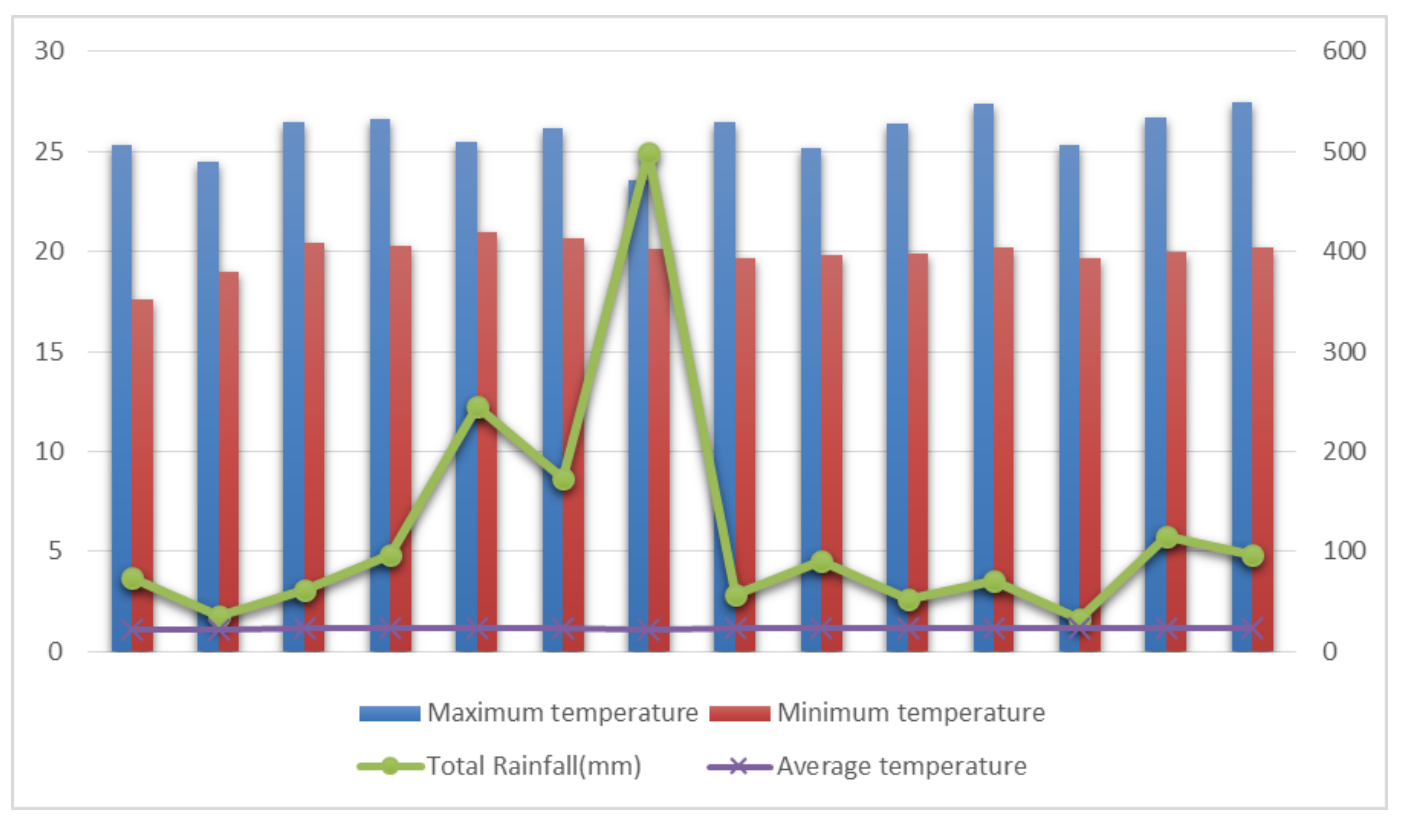

Fig 1: Standard week-wise meteorological data during the crop season 


\section{Results and Discussion \\ Plant height (cm)}

Plant height is an observable parameter that can differentiate the treatments response. The height of black gram plant observed under different phosphorus and boron combinations is presented in Fig. 2. It increased with crop development stages i.e. 30 DAS, 60 DAS and at maturity. Increasing phosphorus and boron doses also increased plant height over control at all crop development stages i.e. 30 DAS, 60 DAS and at maturity. At 30 DAS, under different phosphorus doses, the highest plant height $(20.48 \mathrm{~cm})$ was recorded at 75 $\mathrm{kg} \mathrm{P}_{2} \mathrm{O}_{5} \mathrm{ha}^{-1}$, however, the significant increase was observed up to $50 \mathrm{~kg} \mathrm{P}_{2} \mathrm{O}_{5} \mathrm{ha}^{-1}$ with $20.01 \mathrm{~cm}$. Similarly, under different boron doses, the highest plant height $(20.13 \mathrm{~cm})$ was observed at $1.5 \mathrm{~kg} \mathrm{~B} \mathrm{ha-1}$. The lowest plant height was recorded in control plots of $\mathrm{P}$ and $\mathrm{B}$ with 15.64 and $16.24 \mathrm{~cm}$, respectively.

The similar trend in plant height of black gram was observed at 60 DAS and at maturity stage. The highest plant height at 60 DAS among different phosphorus doses was recorded at $75 \mathrm{~kg} \mathrm{P}_{2} \mathrm{O}_{5} \mathrm{ha}^{-1}$ with $38.44 \mathrm{~cm}$, however, the significant increase was observed up to $50 \mathrm{~kg} \mathrm{P}_{2} \mathrm{O}_{5} \mathrm{ha}^{-1}$ with $37.58 \mathrm{~cm}$ height. Similarly, under different boron doses, the highest plant height $(37.22 \mathrm{~cm})$ was observed at $1.5 \mathrm{~kg} \mathrm{~B} \mathrm{ha-1}$. Contrary to this, the lowest plant height was recorded in control plots of $\mathrm{P}$ and $\mathrm{B}$ with 30.45 and $32.50 \mathrm{~cm}$, respectively. Following the similar pattern, the highest plant height at maturity under different phosphorus doses was recorded at $75 \mathrm{~kg} \mathrm{P}_{2} \mathrm{O}_{5} \mathrm{ha}^{-1}$ as $43.43 \mathrm{~cm}$. Here also, the significant increase was observed up to $50 \mathrm{~kg} \mathrm{P}_{2} \mathrm{O}_{5} \mathrm{ha}^{-1}$ with $42.89 \mathrm{~cm}$ height. Similarly, under different boron doses, the highest plant height $(42.60 \mathrm{~cm})$ was observed at $1.5 \mathrm{~kg} \mathrm{~B} \mathrm{ha}^{-1}$ whereas, the lowest plant height was recorded in control plots of $\mathrm{P}$ and $\mathrm{B}$ as 36.58 and $38.17 \mathrm{~cm}$, respectively at maturity. The increase in plant height with the application of $\mathrm{P}$ might be attributed to the poor available $\mathrm{P}$ status of the experimental soil as well the highly responsive nature of the black gram to $\mathrm{P}$ application. Further, it might also be due to enhanced photosynthetic rate thereby encouraging the vegetative growth (El-Habbasha et al., 2007) ${ }^{[23]}$. Similarly, increased plant height of black gram with the application of boron might be due to more cell division and cell elongation resulting in enhanced plant growth and plant height (Camacho-Cristóbal et al., 2015) ${ }^{[24]}$.

The interaction effect of phosphorus and boron on plant height was also found to be significant at all crop development stages. Within the same level of boron, increasing phosphorus doses increased the plant height, but significantly higher plant height at 30 DAS $(20.04 \mathrm{~cm})$ and 60 DAS $(39.31 \mathrm{~cm})$ was found with the application of $\mathrm{P}_{50} \mathrm{~B}_{1.5}$ whereas at maturity, the plant height was recorded maximum $(43.01 \mathrm{~cm})$ at $\mathrm{P}_{50} \mathrm{~B}_{0.5}$. Similarly, within the same level of phosphorus, the increasing boron doses increased the plant height of black gram but the significant increase in plant height was observed at $\mathrm{P}_{75} \mathrm{~B}_{1}$ as $21.86 \mathrm{~cm}, \mathrm{P}_{50} \mathrm{~B}_{1}$ as $38.87 \mathrm{~cm}$ and $\mathrm{P}_{75} \mathrm{~B}_{0.5}$ as $43.58 \mathrm{~cm}$ at 30,60 DAS and at maturity stage. The lowest plant height was observed in control i.e. $\mathrm{P}_{0} \mathrm{~B}_{0}$ as $13.21 \mathrm{~cm}, 27.14 \mathrm{~cm}, 34.24 \mathrm{~cm}$ at 30, 60 DAS and at maturity stage. The similar results were observed by Sentimenla et al. (2012) ${ }^{[25]}$ who reported that different levels of phosphorus and boron increased plant height of soybean significantly. Kabir et al., (2013) [26] also reported that the combined application of $\mathrm{P}$ and $\mathrm{B}$ increased the plant height of groundnut over control plots. Similar findings were reported by Singh et al., (1989) ${ }^{[27]}$ in French bean.

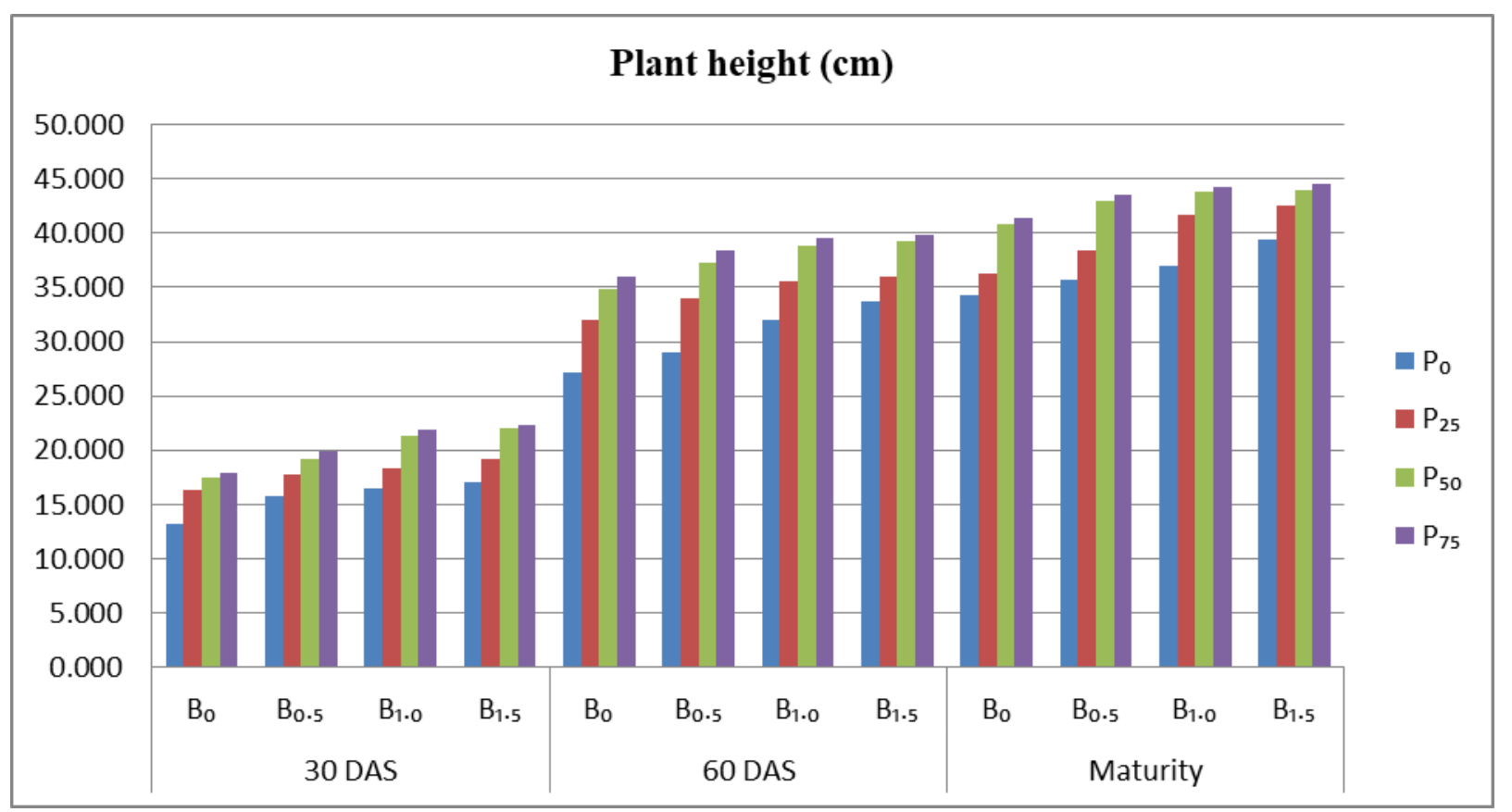

Fig 2: Effect of phosphorus and boron on plant height of black gram at 30, 60 DAS and at maturity stage in acidic soil of Meghalaya

\section{Seed yield $\left(\mathbf{q} \mathbf{h a}^{-1}\right)$}

The data pertaining to seed yield of black gram is presented in Table 2. The seed yield increased with increasing phosphorus and boron doses. The highest seed yield (10.12 $\left.\mathrm{q} \mathrm{ha}^{-1}\right)$ among different phosphorus doses was observed at $75 \mathrm{~kg} \mathrm{P}_{2} \mathrm{O}_{5} \mathrm{ha}^{-1}$. However, significant increase in seed yield was recorded up to $50 \mathrm{~kg} \mathrm{P}_{2} \mathrm{O}_{5} \mathrm{ha}^{-1}$ with $9.52 \mathrm{q} \mathrm{ha}^{-1}$. The lowest seed yield was recorded in control plots as $6.41 \mathrm{q} \mathrm{ha}^{-1}$. With successive boron doses, the lowest seed yield i.e. $7.19 \mathrm{q} \mathrm{ha}^{-1}$ was obtained at control, although significant increased seed yield was observed up to $1.0 \mathrm{~kg} \mathrm{~B} \mathrm{ha}^{-1}$ as $9.13 \mathrm{q} \mathrm{ha}^{-1}$ yet the highest seed yield was recorded as $9.43 \mathrm{q} \mathrm{ha}^{-1}$ at $1.5 \mathrm{~kg} \mathrm{~B} \mathrm{ha}^{-1}$. The interaction effect of phosphorus and boron on seed yield was also found significant. The lowest seed yield was observed in 
control at $\mathrm{P}_{0} \mathrm{~B}_{0}$ as $5.56 \mathrm{q} \mathrm{ha}^{-1}$ and significantly highest seed yield was observed at $\mathrm{P}_{50} \mathrm{~B}_{1.5}$ as $10.35 \mathrm{q} \mathrm{ha}^{-1}$ at phosphorus within boron and in boron within phosphorus as $11.03 \mathrm{q} \mathrm{ha}^{-1}$ at $\mathrm{P}_{75} \mathrm{~B}_{1}$.

The increase in seed yield with the increasing phosphorus application might be due to improvement in plant growth and vigour as phosphorus plays important role in plant metabolism finally leading to enhanced seed yield. The improvement in seed yield can also be attributed to the role of boron in stabilizing certain constituents of cell wall and plasma membrane, enhancement of cell division, tissue differentiation and metabolism of nucleic acids, carbohydrates, proteins, auxins and phenols (Marschner 1986) ${ }^{[28]}$. Kamboj and Malik (2018) ${ }^{[29]}$ reported that increase in phosphorus and boron doses increases the seed yield of black gram with highest yield recorded on combined application of $100 \mathrm{mg} \mathrm{P} \mathrm{kg}{ }^{-1}$ along with $1.0 \mathrm{mg} \mathrm{B} \mathrm{kg}{ }^{-1}$. Chowdhury et al., (2015) [30] also reported that interaction effect of $\mathrm{P}$ and $\mathrm{B}$ significantly influenced the quality attributes of lettuce seeds and also found that application of $120 \mathrm{~kg} \mathrm{P}_{2} \mathrm{O}_{5} \mathrm{~kg} \mathrm{ha}^{-1}$ and 2 $\mathrm{kg} \mathrm{B} \mathrm{ha}{ }^{-1}$ was better combination for better growth, yield and quality of lettuce.

Table 2: Effect of phosphorus and boron on seed yield $\left(\mathrm{q} \mathrm{ha}^{-1}\right)$ of black gram in acidic soil of Meghalaya

\begin{tabular}{|c|c|c|c|c|c|}
\hline \multicolumn{5}{|c|}{ Seed yield $\left(\mathrm{q} \mathrm{ha}^{-1}\right)$} \\
\hline Treatments & $\mathbf{B}_{\mathbf{0}}$ & $\mathbf{B}_{\mathbf{0 . 5}}$ & $\mathbf{B}_{\mathbf{1 . 0}}$ & $\mathbf{B}_{\mathbf{1 . 5}}$ & Mean \\
\hline $\mathrm{P}_{0}$ & 5.56 & 6.20 & 6.70 & 7.17 & 6.406 \\
\hline $\mathrm{P}_{25}$ & 6.57 & 7.80 & 8.65 & 8.72 & 7.933 \\
\hline $\mathrm{P}_{50}$ & 8.28 & 9.32 & 10.14 & 10.35 & 9.523 \\
\hline $\mathrm{P}_{75}$ & 8.37 & 9.65 & 11.03 & 11.47 & 10.128 \\
\hline Mean & 7.193 & 8.242 & 9.129 & 9.427 & 8.498 \\
\hline & \multicolumn{3}{|c|}{ SE(m) \pm} & \multicolumn{3}{c|}{ C.D $(p<0.05)$} \\
\hline P & 0.419 & \multicolumn{3}{c|}{1.451} \\
\hline B & 0.105 & \multicolumn{3}{c|}{0.306} \\
\hline P within B & 0.457 & \multicolumn{3}{c|}{1.542} \\
\hline B within P & \multicolumn{2}{|c|}{0.210} & \multicolumn{3}{c}{012} \\
\hline
\end{tabular}

\section{Conclusion}

The results of the investigation suggested that the combined application of $\mathrm{P}$ and $\mathrm{B}$ had significant effect on seed yield of black gram with increasing levels of $\mathrm{P}$ and $\mathrm{B}$ up to $50 \mathrm{~kg} \mathrm{P}_{2} \mathrm{O}_{5}$ $\mathrm{ha}^{-1}$ and $1.5 \mathrm{~kg} \mathrm{~B} \mathrm{ha}^{-1}$, respectively clearly indicating their synergistic effect in acidic soil of Meghalaya.

\section{Acknowledgement:}

The laboratory facility provided by School of Natural Resource Management, College of Post Graduate Studies in Agricultural Sciences, CAU, Umiam for carrying out soil analysis is duly acknowledged.

\section{References}

1. Brady NC, Weil RR. The Nature and Properties of Soils. $14^{\text {th }}$ edition. Prentice Hall, Upper Saddle River, New Jersey, USA, 2008, 1104.

2. Sanjay-Swami, Singh S. Effect of nitrogen application through urea and Azolla on yield, nutrient uptake of rice and soil acidity indices in acidic soil of Meghalaya. J Environ. Biol. 2020; 41(1):139-146.

3. Nasreen S, Shil NC, Hossain MA, Farid ATM. Effects of phosphorous and sulphur application on the yield and yield components of garden pea. Bangladesh J Agril. Res. 2006; 31(4):673-679.

4. Sailo V, Sanjay-Swami. Performance of pea (Pisum sativum L.) with residual phosphorus in phytoremediated heavy metal polluted soil of Jaintia hills, Meghalaya. Int. J Chem Studies. 2019; 7(3):3270-3273.

5. Alinajoati SS, Mirshekari B. Effect of phosphorus fertilization and seed biofertilization on harvest index and phosphorus use efficiency of wheat cultivars. J Food Agric. Environ. 2011; 9(2):388-397.

6. Atif MJ, Shaukat SA, Shah SZA, Choudhry YA, Shaukat SK. Effect of different levels of phosphorus on growth and productivity of pea (Pisum sativum L.) cultivars grown as offseason under rawalakot azad Jammu and Kashmir conditions. J Recent Adv. Agric. 2014; 2(6):252-257.

7. Oyinlola EY. Effect of boron fertilizer on yield and oil content of three sunflower cultivars in the Nigerian Savanna. J Agron. 2007; 6(3):421-426.

8. Marschner P. Marschner's Mineral Nutrition of Higher Plants. Academic Press, New York, USA, 2012, 672.

9. Gupta U, Solanki H. x Impact of boron deficiency on plant growth. Int. J Bioassays. 2012; 2:1048-1050.

10. Rio Tinto. Functions of Boron in Plant Nutrition. Agronomy Note, 2012.

https://www.researchgate.net/profile/Anoop_Srivastava7/ post/What_is_the_role_of_boron_in_seed_production/att achment/59d62cba79197b807798b07e/AS\%3A34785682 $2128641 \% 401459946937554 /$ download/functionsofboro ninplantnutrition-final-feb2012.pdf

11. Marschner H. Mineral nutrition of higher plants. II Ed. Academic Press Inc. London, 1995, 889.

12. Camocho-Cristobal JJ, Martin-Rejano EM, HerreraRodriguez MB, Navarro-Gochicoa MT, Rexach J, Gonzalez-Fontes A. Boron deficiency inhibits root cell elongation via an ethylene/ auxin/ ROS-dependent pathway in Aradidopsis seedlings. J Expt. Bot., 2015; 66(13):3831-3840.

13. Singh RN, Singh, Surendra, Kumar V. Interaction effect of sulphur and boron on yield, nutrient uptake and quality characters of soybean (Glycine max L. Merill) grown in acidic upland soil. J Indian Soc. Soil Sci. 2006; 54:516518.

14. Nelyubova GL, Sychev YP. Efficacy of boron in relation to the level of phosphorus. [In Russian.] Dokh Mosk SKh Akad Im K. A. Timiryazev. 1969; 154:135-139.

15. Bould C. Methods of diagnosing nutrient disorders in plants. In: J. B. D. Robinson (ed.) Diagnosis of mineral disorders in plants, Principles H.M.S.O. London, U.K, 1983; I:111-136.

16. Hundt I, Schilling G, Fischer F, Bergmann W. Investigations on the influence of micronutrient boron on nucleic acid metabolism. [In German] Thaer-Arch. 1970; 14:725-737.

17. Kevresan S, Grujic S, Kastori R, Kandrac T. Study of rhe ratio of some groups of nucleic acids in relation to boron nutrition. Zemljiste Blljke. 1977; 26:57-64.

18. Dugger WM. Boron in plant metabolism. ln: A. Pirson and M. H. Zimmermann, eds. Encyclopedia of plant physiology. (New Series). Springer-Verlag, Berlin. 1983; 158:626-650.

19. Hewitt EJ, Tatham P. Interaction of minerai deficiency and nitrogen supply on acid phosphatase activity in leaf extracts. J Exp. Botany. 1960; 11:367-376.

20. Hewitt EJ. The essential and funcrional mineral elements. In: J. B. D. Robinson (ed.) Diagnosis of mineral disorders in plants. Principies, H.M.S.O., London, U.K. 1983; I:53.

21. Tamang B, Sanjay-Swami. Effect of phosphorus and sulphur on nutrient uptake of black gram (Vigna mungo 
L. Hepper) in acid Inceptisol. In: Natural Resource Management for Climate Smart Sustainable Agriculture, (eds.) Sanjay Arora, Sanjay-Swami and Suraj Bhan, Soil Conservation Society of India, New Delhi, 2017; 298309. ISBN: 978-81-909228-8-3.

22. Tamang B, Sanjay-Swami. Temporal availability of phosphorus and sulphur in acid Inceptisol as influenced by graded application of $\mathrm{P}$ and $\mathrm{S}$ under black gram (Vigna mungo L. Hepper) production. Legume Res.: An Inter. J. 2019, DOI: 10.18805/LR-4127.

23. El-Habbasha SF, Hozayn M, Khalafallah MA. Integration effect between phosphorus levels and biofertilizers on quality and quantity yield of Faba bean (Vicia faba L.) in newly cultivated sandy soils. Res. J Agric. Biol. Sci. 2007; 3(6): 966-971.

24. Camocho-Cristobal JJ, Martin-Rejano EM, HerreraRodriguez MB, Navarro-Gochicoa MT, Rexach J, Gonzalez-Fontes A. Boron deficiency inhibits root cell elongation via an ethylene/ auxin/ ROS-dependent pathway in Aradidopsis seedlings. J Exp. Botany. 2015; 66(13):3831-3840.

25. Sentimenla, Singh AK, Singh S. Response of soybean to phosphorus and boron fertilization in acidic upland soil of Nagaland. J Indian Soc. Soil Sci. 2012; 60(2):1-4.

26. Kabir R, Yeasmin S, Islam AKMM, Sarkar MAR. Effect of phosphorus, calcium and boron on the growth and yield of groundnut (Arachis hypogea L.). Int. J Biosci. Bio-Technol. 2013; 5(3):51-59.

27. Singh BP, Singh B, Singh BN. Influence of phosphorus and boron on picking behaviour and quality of French bean (Phaseolus vulgaris) under limited irrigation, grown in Alfisols deficient in phosphorus and boron. Indian $\mathbf{J}$ Agric. Sci. 1989; 59:541-543.

28. Marschner H. Mineral nutrition of higher plants. Academic Press, London, 1986.

29. Kamboj N, Malik RS. Influence of phosphorus and boron application on yield, quality, nutrient content and their uptake by green gram (Vigna radiate L.). Int. J Curr. Microbiol. App. Sci., 2018; 7(3):1451-1458.

30. Chowdhury SZ, Sobhan MA, Shamim AHM, Akter N, Hossain MM. Interaction effect of phosphorus and boron on yield and quality of lettuce. Azarian J Agric. 2015; 2(6):147-154. 